\title{
NOMINAL WORD FORMATIONS IN TOBA BATAK LANGUAGE: A STUDY OF GENERATIVE MORPHOLOGY
}

\author{
Esron Ambarita, Robert Sibarani, Dwi Widayati, Eddy Setia \\ Postgraduate Department of Linguistics, Faculty of Cultural Sciences \\ University of Sumatera UtaraMedan, Indonesia \\ Corresponding author: esronambarita@gmail.com
}

\begin{abstract}
The objective of this paper is to explore nominal word formations in Toba Batak language. The theory applied in this study is generative morphology proposed by Halle (1973). The basic principle in generative morphology is that the process of word formations can generate actual words and potential words. According to generative morphology the mechanism of word formations will be postulated in list of morphemes, word formation rules, filter, and dictionary. The method of this study is qualitative descriptive; it is a method of study which describes language phenomena naturally without any exception. The results show that nominal word formations in Toba Batak language are distinguished in 3 main ways, they are: [1] by attaching affixations, [2] by inserting premodifier ni between adjectival bases and nominal bases, and [3] by moving the stress of free adjectival bases from the first syllable to the second syllable. There are 14 affixations that can form nouns in Toba Batak language, they are: (i) six prefixes (par-, na-, sa-, sanha-, hina-, ha-), (ii) two infixes (-ar-, -al-), (iii) one suffix (-na), (iv) four multiple affixations (ha-...-on, $p a-\ldots-a n, p a-\ldots-o n, p a r-\ldots-a n)$, and (v) double affixations (par-in-). Nominal word formations derive from various free word bases, such as, free adjectival bases, free verbal bases, free nominal bases, free numeric bases, and free adverbial bases. The results of these affixations can be inflectional or derivational. Some complex words have to be put into filter to be processed morphophonologically before they are put into dictionary.
\end{abstract}

Keywords: nominal word formations, affixations, generative morphology, inflectional, derivational

\section{Introduction}

Toba Batak language is one of the regional languages in Indonesia especially in North Sumatra province. Language cannot be separated from culture. What people mean is realized in language. Therefore, linguistics and cultures are the centre of analysis in the process of translating human's activities (Sembiring, 2016: 1142). In most villages in Tano Batak 'Batak Land' such as Samosir sub district, Toba Samosir sub district, Humbang Hasundutan sub district, and Tapanuli Utara sub district Toba Batak 
language is used in daily social interaction. A person might utter one sentence in different ways depends on where he is, with whom he is speaking to, etc. (Ambarita, 2017a: 8557). Toba Batak language belongs to Austronesian spoken by 3 million people in Sumatra (Crystal, 1993: 40). There have been a lot of studies on generative morphology, such as Loe (2018), Zainuddin (2012), Nasution (2011), Sukri (2008), Simpen (2008), Murdiyanto (2000), etc.

\section{Literature Review}

\section{A Brief Note on Word Formations}

Morphology is the study of morphemes and their arrangements in forming words (Haspelmath et al, 2002: 1). Morphemes as elements of words play important roles in word formation, therefore, there are a lot of morphological issues that can be discussed, not only free morphemes but also bound morphemes (Ambarita, 2017d: 131). In other words, a base morpheme can be modified in order to form new word by affixation processes (Ambarita, 2017c: 131). Affixations are divided into four types, namely, prefixations, infixations, suffixations, and multi affixations.

\section{Theoretical Frame}

According to generative morphology in Halle's model (1973), the rules of word formation would then tell us among other things how the morphemes are to be arranged in sequences to form actual words (Halle, 1973: 4). Halle suggested that morphology consists of three distinct components, they are: (1) List of Morpheme, (2) Word Formation Rules, and (3) Filter containing the idiosyncratic properties of words. One can think of the morphology, then, as producing a long list of words is designated by the term dictionary (Halle, 1973; Aronoff, 1976, and Djardjowidjojo, 1988).

List of Morphemes includes roots, stems, bases, and affixes. It is the Word Formation Rules that determines how the morphemes of a language are arranged in sequences to form the actual words of that language. Word Formation Rules must be able to generate all the well-formed words of a language and exclude the ill-formed ones. The words of a language, however, cannot be derived wholly by means of regular rules because there exist semantic, phonological, and lexical idiosyncrasies (Scalise, 1984: 25). Halle proposes to treat such words in Filter. The words that actually pass through the Filter constitute Dictionary of the language as the final component.

\section{Research Methods}

This study applied qualitative descriptive method. This study is intended to describe the real phenomena of Toba Batak language. This study is both documentary and field research because the data were originated from written and oral sources.

\section{Discussions}


In reference to word formations in generative morphology (Halle, 1973: 8) there are four integrated components required, they are List of Morphemes, Word Formation Rules, Filter, and Dictionary.

\section{List of Morphemes}

Parts of word formations in List of Morphemes are realized as roots, stems, bases, and affixes. List of Morphemes in Toba Batak language are manifested in free word root, stems, bases, and affixes, such as prefixes, infixes, suffixes, and multi affixations (Ambarita, 2017b: 191). The affixes that can generate nouns in Toba Batak language is discussed in the following parts. Apart from free word bases, affixations are the other elements of List of morphemes. This study found that nominal affixations in Toba Batak language are distinguished into five types of affixations, they are: [1] prefixes (e.g. par-, na-, sa-, sanha-, hina-, and ha-), [2] infixes (e.g. -ar- andal-), [3] suffix (e.g. $-a n)$, [4] multi affixations (e.g. ha-...-on, pa-...-an, pa-...on, and par-...-an), and [5] double affixations (e.g. par-in-).

\section{Word Formation Rules}

Nominal word formations as the central issue in this study can be derived from various free word bases, such as, free adjectival bases, free verbal bases, free nominal bases, free numeric bases, and free adverbial bases. The results of these affixations can be inflectional or derivational.

\section{Nominal Word Formations}

Based on the data collected, nominal word formations in Toba Batak language are distinguished in 3 main ways, they are: [1] by attaching affixations, [2] by inserting premodifier $n i$ between adjectival bases and nominal bases, and [3] by moving the stress of free adjectival bases from the first syllable to the second syllable.

\section{Prefix par-}

Prefix par- can be inflectional and derivational. Prefix par- is inflectional if it is attached to free nominal bases as in the following data.
[1] parhuta
'villagers'
[2] parhoda
'the horse's owner'

The forms parhuta and parhoda as complex words are formed from free nominal bases huta 'village' and hoda 'horse' respectively by attaching prefix -par. The attachment of prefix par-both to huta and to hoda as nouns does not alter the word class. Therefore, prefix par-is inflectional. Besides, prefix par- can also be derivational if it is attached to free verbal bases as in the following data.
[3] parkarejo
'worker'
[4] parjuji
'gambler'

The attachment of prefix par- both to karejo 'work' and to juji as verbs changes the word class to noun. Therefore, prefix par-is inflectional. The meaning of prefix par- in this context is person who .... as indicated by the free verbal bases karejo and juji. Juji is a precategorial lexeme or a stem which does not have syntactic category. It can only have meaning after affix is attached. There is another variation of prefix par- to negate expression as shown in [5]. 


\section{[5] par-dang-girgir 'unhappiness'}

Par-dang-girgir is formed from free adjectival base girgir 'happy' + dang 'not' -> dang girgir 'will not'. Furthermore, prefix par- is attached to dang girgir $\rightarrow$ par-dang-girgir 'unwillingness'. Prefix par- in this word formation is derivational because it changes the word class from adjective becomes noun.

\section{Prefix na-}

Prefix na-functions as derivational affix if it is attached to free adjectival bases as in the following data.
[6] natigor
'fair person'
[7] namalo
'clever person'

From data [6] and [7] it can be seen that prefix na- is derivational because its attachment to free adjectival bases tigor 'fair' and malo 'clever' respectively changes the word class to nouns. The combination of prefix na-to free adjectival base encodes person as indicated by the base morpheme to which the affix is attached.

\section{Prefix sa-}

Prefix sa- is inflectional if it is attached to free nominal bases as in the following data.
[8] sandangka
'one branch (of fruit)'
[9] sansisir
'one bunch (of banana)

The free nominal bases of sandangka and sansisir are dangka 'branch' and sisir 'scraper'. Prefix sa- is a bound morpheme. Thus, sa- + dangka -> *sadangka and sa- + sisir $\rightarrow{ }^{*}$ sasisir. There is phonological idiosyncrasy in [8] and [9]. Therefore, these forms must enter FILTER to have morphophonological processes.

$\begin{array}{ll}\text { Deep Structure } & :{ }^{*}[\#[\text { sa-]pref }+[\text { danka] NP\#]N } \\ \text { Additional phoneme /n/ } & :{ }^{*}[\#[\text { sa-]pref }+/ \mathrm{n} /+[\text { danka] NP\#]N } \\ \text { Surface Structure } & : \text { sandangka } \\ & :{ }^{*}[\#[\text { sa-]pref }+[\text { sisir] NB\#]N } \\ \text { Deep Structure } & :{ }^{*}[\#[\text { sa-]pref }+/ \mathrm{n} /+[\text { sisir] NB\#]N } \\ \text { Additional phoneme } / \mathrm{n} / & : \text { sansisir }\end{array}$

The forms sandangka and sansisir are now ready to be put into dictionary.

\section{Prefix sanha-}

Prefix sanha- belongs to inflectional affix because its attachment to free word base does not change the word class as presented below.

[10] sanhabona 'one trunk (of tree)'

[11] sanhababa 'one piece (of word)'

The forms sanhabona and sanhababa are complex words formed from free nominal bases bona 'trunk' and baba 'mouth' as simple words. The combination of the two morphemes brings new meaning to prefix sanha- that is one.

\section{Prefix ha-}

Prefix ha- can be attached to free verbal bases, free numerical base, and to free adjectival bases. However, there is a special word formation rule for this category. The 
first syllable of verb or adjective to which prefix $h a$ - is attached is doubled until vowel sounds as follows.
[12] haboborhat
[13] haoopat
'departure'
[14] hariringgas
'the four'
'diligence'

The forms haboborhat, haoopat, and hariringgas are formed from simple words borhat, opat, and ringgas by attaching prefix ha- added by the first syllable of the word until vowel sound. The first syllables of the word borhat, opat, and ringgas are bor-, $\mathrm{O}^{-}$, and ring- respectively. The forms bor-, $\mathrm{O}_{-}$, and ring- as the first syllables of those words until vowel sound are bo-from bor-, $o_{-}^{-}$, and ri-from ring-. Later, bo-, $o^{-}$, and $r$ - are attached to borhat and ringgas which generate bo-borhat, o-opat, and riringgas. Finally they are added by prefix ha- to form ha-bo-borhat, ha-o-opat, and hari-ringgas. Based on the data above, prefix ha- is derivational.

\section{Prefix hina-}

Prefix hina- can be attached to free adjectival bases as in the data below.
[15] hinadenggan
'kindness'
[16] hinaroa
'ugliness'

The function of prefix hina- is derivational if it is attached to free adjectival bases. The forms hinadenggan and hinaroa are formed from simple words denggan and roa respectively. The meaning of prefix hina- in this data is the quality of being .... as mentioned by the free adjectival bases. There is another variation of prefix hina- to negate expression as shown in [17].

[17] hina-so-olo 'unwillingness'

Hina-so-olo is formed from free adjectival base olo 'will' + so 'not' -> so olo 'will not'. Furthermore, prefix hina- is attached to so-olo $\rightarrow$ hina-so-olo 'unwillingness'. Prefix hina- in this word formation is derivational because it changes the word class from adjective to noun.

\section{Prefix ha-}

Prefix ha- as a derivational affix can integrate with word combination in which the base of the word combination is adjectival bases.
[18] ha-so-ra-malumon
'the impossibility to get recovered'.
[19] ha-hurang-turean
'the quality of being less kind'
[20] ha-dang-olo
'unwillingness'
[21] ha-nabadiaon
'the quality of being holy'

The form ha-so-ra-malumon is a very complex word combination which is formed from free adjectival base malum 'recovered'. The sequence of processes to form the word ha-so-ra-malumon is started by presenting premodifier ra 'possible' to malum $\rightarrow$ ra-malum. Later, premodifier so 'not' is attached to ra-malum $\rightarrow$ so-ra-malum 'not possible to get recovered'. Finally, confix ha-...-on is attached to so-ra-malum -> ha-sora-malumon 'the impossibility to get recovered'. The same procedures also occur to [19], [20], and [21].

Infix -ar- 
Infix -par-can be inflectional and derivational. Infix -par-is inflectional if it is attached to free nominal bases, such as in [22], [23], [24], and [25].
[22] darede
'saliva'
[23] barungbung
'a valley between two mountains'
[24] haratak 'sound tak-tak-tak
[25] haruok
'the name of bird of which the sound is huok huok huok'

The forms darede, barungbung, haratak, and haruok as complex words are formed from nominal bases morphemes dede 'a drop of saliva', bungbung 'a big open hole', hatak 'sound tak', and huok 'sound huok'. The attachment of infix -ar- to nominal bases indicates plural or look like .... as indicated by the nominal bases. Infix -ar- can also be attached to verbal base category as in [26] and [27].
[26] hariar
[27] garantung

'the handle of a spoon'

'traditional musical instrument for Toba Batak ethnic consisting of five pieces hung when they are played'

The forms hariar and garantung are complex words. They are formed from simple forms hiar 'scrape (sth, usually rice) out of container' and gantung 'hang' as transitive verbs that need the presence of objects in sentence valence. The attachment of infix ar- both to hiar and to gantung as verbs alters the word class becomes nouns. Therefore, infix -in-is derivational. The meaning of infix -ar-shows the noun of the verbal bases. Infix -in- can also be attached to free adjectival base, such as in [28] below.

[28] harungkut 'contraction'

The form harungkut is a complex word which is formed from lexeme hungkut 'wrinkled' by attaching infix -in- within the free adjectival base hungkut. Therefore, infix -in- + hungkut -> harungkut.

\section{Infix $-a \mid-$}

Infix - al- is an alternative usage of infix - ar- that can be inserted within free nominal base. In this context, dental phoneme / $\mathrm{r} /$ and /I/ are interchangeable reciprocally as shown in the following data.

$\begin{array}{llll}\text { [29] hosuk 'civet' } & \rightarrow \text { halosuk /harosuk } & \text { 'civets or civets like' } \\ \text { [30] gunsang } & \text { 'shake' } & \text { > galunsang/garunsang } & \text { 'sea wave' } \\ \text { [31] gege } & \text { 'torture' } & \text {-> galege /garege } & \text { 'troublemaker' } \\ \text { [32] tindan } & \text { 'crooked' } \rightarrow \text { talindan /tarindan } & \text { 'crooked root' }\end{array}$

\section{Suffix -na}

Suffix $-n a$ is a derivational affix because it changes the word class to which the affix is attached as in the following data.
[33] ulina
'beauty'
[34] timbona
'height'

Ulina and timbona are formed from uli and timbo as adjectives. It can be seen clearly that the attachment of bound morpheme -na to free adjectival base changes the adjectives becomes nouns. Therefore, suffix -na is a derivational affix. 


\section{Multiple Affixations ha-on}

Multiple affixations $h a-\ldots$-on is a derivational affix as presented in the following data.

\begin{tabular}{|l|c|c|c|c|c|}
\hline No & $\begin{array}{c}\text { Adjectival } \\
\text { Base }\end{array}$ & Gloss & ha-...-on & Gloss & $\begin{array}{c}\text { Form } \\
\text { Change }\end{array}$ \\
\hline 35 & hipas & healthy & hahipason & health & Adj $->N$ \\
\hline 36 & mora & wealth & hamoraon & wealthy & Adj $>\mathrm{N}$ \\
\hline
\end{tabular}

The forms hahipason, hamoraon, hasangapon, and hajorbuton as complex words are formed from adjectival base morphemes hipas, mora, sangap, and jorbut respectively by attaching multiple affixations $h a-. . .-o n$.

\section{Multiple Affixations $p a-. .$. -an}

Multiple affixations $p a-. . .-a n$ is a derivational affix because it changes the free verbal base to noun as in the following data.
[37] lompa $\quad \rightarrow$ pangalompaan
[38] sungkun -> panungkunan
[39] seat $\quad \rightarrow$ paneatan
[40] pele $\quad \rightarrow$ pamelean

Those forms must enter filter to be processed.
Deep Structure
$:{ }^{*}[\#[$ pa-an]M. Affixations + [lompa] VB\#]N
Additional phoneme /na/
$: *[\#[$ pa-an]M. Affixations +/na/ + [lompa] VB\#]N
Surface Structure
: pangalompaan

Similar process also occurs to other data.

\section{Multiple Affixations $p a-. .$. -on}

Multiple affixations $p a-\ldots$-on is a derivational affixation because it changes the free verbal base to noun as in the following data.

$$
\begin{aligned}
& \text { antusi + pa-...-on -> pangantusion } \\
& \text { tanom + pa-...-on -> pananomon } \\
& \text { pinsang + pa-...on -> pamissangon } \\
& \text { hophop + pa-...-on -> panghophopon }
\end{aligned}
$$

The forms pangantusion, pananomon, paminsangon, and panghophopon as complex words are formed from free verbal bases antusi, tanom, pinsang, and hophop respectively by attaching confix pa-...-on. Free verbal bases antusi $+p a-\ldots$-..on $->$

\begin{tabular}{|c|c|}
\hline Deep Structure & $: *[\#[$ pa-on]M. Affixations $+[$ antusi] VB\#]N \\
\hline $\begin{array}{l}\text { Additional phoneme } / \eta / \\
\text { Surface Structure }\end{array}$ & $\begin{array}{l}:{ }^{*}[\#[\text { pa-on]M. Affixations }+/ \eta /+[\text { antusi }] \text { VB\#]N } \\
: \text { pangantusion }\end{array}$ \\
\hline Deep Structure & $: *[\#[$ pa-on] $]$. Affixations $+[$ tanom $]$ VB\#]N \\
\hline $\begin{array}{l}\text { Phoneme assimilation /n/ } \\
\text { Surface Structure }\end{array}$ & $\begin{array}{l}: *[\#[\text { pa-on }] M . \text { Affixations }+/ \mathrm{n} /+[\text { tanom }] \text { VB\#]N } \\
: \text { pananomon }\end{array}$ \\
\hline Deep Structure & $: *[\#[$ pa-on] $]$. Affixations $+[$ pinsan] VB\#]N \\
\hline Phoneme assimilation /m/ & $: *[\#[$ pa-on]M. Affixations $+/ m /+[$ pinsan $]$ \\
\hline
\end{tabular}
*paantusion, tanom + pa-...-on $\rightarrow$ *patanomon, pinsang + pa-...-on $\rightarrow$ *papinsangon, hophop $+p a-. . .-$ on $\rightarrow{ }^{*}$ pahophopon. These forms cannot enter DICTIONARY before they are processed in FILTER. 


$$
\begin{array}{ll}
\text { Surface Structure } & : \text { paminsangon } \\
\text { Deep Structure } & : *[\#[\text { pa-on]M. Affixations + [hokkop] VB\#]N } \\
\text { Additional phoneme } / \eta / & : *[\#[\text { pa-on]M. Affixations }+/ \eta /+[\text { antusi] VB\#]N } \\
\text { Surface Structure } & : \text { panghophopon }
\end{array}
$$

The form pangantusion, pananomon, paminsangon, and panghophopon are now ready to be put into dictionary.

Multiple Affixations par-... -an

Multiple affixations par-...-an can be attached to verbs as in the following data.

\begin{tabular}{|l|l|l|l|l|l|}
\hline No & Verbal Base & \multicolumn{1}{|c|}{ Gloss } & \multicolumn{1}{c|}{ par-...-an } & \multicolumn{1}{c|}{ Gloss } & Form Change \\
\hline 41 & dahan & cook & pardahanan & place for cooking rice & V $->\mathrm{N}$ \\
\hline 42 & saor & mix & parsaoran & the way to socialize & V $->\mathrm{N}$ \\
\hline 43 & mangan & eat & parmanganan & place for eating & V $->\mathrm{N}$ \\
\hline 44 & juji & gambling & parjujian & place for gambling & V $>\mathrm{N}$ \\
\hline
\end{tabular}

The forms pardahanan, parsaoran, parmanganan, and parjujian as complex words are formed from free verbal bases dahan, saor, mangan, and juji respectively by attaching confix par-...-an. The attachment of multiple affixations par-...-an to free verbal bases changes the word class from verb to noun.

Multiple affixations par-...-an can also be attached to nouns as in the following data.

\begin{tabular}{|l|l|l|l|l|l|}
\hline No & Verbal Base & \multicolumn{1}{|c|}{ Gloss } & \multicolumn{1}{c|}{ pa-...-on } & Gloss & Form Change \\
\hline 42 & singkola & school & parsingkolaan & school complex & V $->\mathrm{N}$ \\
\hline 43 & jabu & house & parjabuan & the place to build a house & V $->\mathrm{N}$ \\
\hline 44 & borngin & night & parbornginan & the place to stay at night & V $->\mathrm{N}$ \\
\hline 45 & gadong & cassava & pargadongan & the place to plant cassava & V $->\mathrm{N}$ \\
\hline
\end{tabular}

The forms parsingkolaan, parjabuan, parbornginan, and pargadongan as complex words are formed from free nominal bases singkola, jabu, borngin, and gadong respectively by attaching confix par-...-an. Multiple affixations par-...an is an inflectional affix.

\section{Double Affixations par-in-}

Double affixations are derivational affixes as in [46] and [47].
[46] parsinuan
'father'
[47] parsinonduk 'wife'

Double affixations in parsinuan and parsinonduk are the combination of prefix parand infix -in-. Thus, the base forms of the two complex words are suan 'plant' and sonduk 'scrape (sth, usually rice) out of container' respectively. The meaning of the double affixations is to form figurative expressions.

\section{Inserting Premodifier ni between Adjectival Bases and Nominal Bases}

Besides attaching affixations, inserting premodifier ni between adjectival bases and nominal bases also can form nouns as in [48] and [49].

[48] Dang tarpatudos uli ni Tao Toba hu tao na asing not compared beautiful [PREMODIFIER] Lake Toba to lake which others 'The beauty of Lake Toba cannot be compared to other lakes'
[49] Ise umboto timbo
ni
Gunung Toba najolo? 
Who know high [PREMODIFIER] Mount Toba formerly?

'Who knows the height of Gunung Toba formerly?'

Based on these two sentences, it can be seen clearly that lexemes uli 'beautiful' in [48] and timber 'high' in [49] are adjectives. However, the presence of premodifier ni in the sentences changes the lexical category of uli 'beautiful' (adjective) $\rightarrow$ uli ni 'beauty' (noun) and timbo 'high' (adjective) $\rightarrow$ timbo ni 'height' (noun). In short, by the presence of premodifier ni between free adjectival bases and noun has transformed free adjectival bases to nouns.

\section{Moving the Stress of Free Adjectival Bases from the First Syllable to the Second Syllable}

The last way of forming nouns in Toba Batak language is by moving the stress of free adjectival bases from the first syllable to the second syllable as in [50], [51], and [52].

\begin{tabular}{|l|l|l|l|l|}
\hline No & \multicolumn{1}{|c|}{ Adjectives } & \multicolumn{1}{c|}{ Gloss } & \multicolumn{1}{c|}{ Nouns } & \multicolumn{1}{c|}{ Gloss } \\
\hline 50 & 'garemor & noisy & ga'remour & Noise \\
\hline 51 & 'harumor & humorous & ha'rumor & Humor \\
\hline 52 & 'garellok & crooked & ga'rellok & crooked thing \\
\hline
\end{tabular}

The forms 'garemor, 'harumor, and 'garelllok are adjectives with infix -ar- of which the stress of the words are in the first syllable. However, those words can be generated into nouns by changing the stress of the words to the last second syllables.

\section{Conclusions}

As a theory of which has predictive power, generative morphology is eligible to be applied in language studies to explore language phenomena without exception. The theory stimulates the way of thinking critically. In so doing, other researcher especially linguistic students of master degree and doctoral degree are hoped to do other research using generative morphology to develop new theory. In other words, further research is expected to be theory finding rather than theory application.

\section{REFERENCES}

Ambarita, Esron. (2017a). Sociolinguistic Routines in Social Interactions in Toba Batak Language. Jurnal IImiah KULTURA, Vol. 18 No. 1 Juni 2017, ISSN 1411-0229, Medan: Penerbit Universitas Muslim Nusantara (UMN) AI Wasliyah.

Ambarita, Esron. (2017b). Daftar Morfem dalam Sistem Morfologi Generatif Bahasa Batak Toba. Jurnal TIFA, Volume 9, Nomor 1, Edisi Januari 2017, ISSN: 20887124, Medan: Penerbit Program Pascasarjana S2 Pendidikan Bahasa Indonesia, Universitas Muslim Nusantara Al Wasliyah.

Ambarita, Esron. (2017c). Morphological Analysis of Adjective Reduplications in Toba Batak Language. Jurnal Penelitian Pendidikan Bahasa dan Sastra, Vol. 2 No. 1 April 2017, ISSN: 2502-9584, Medan: Penerbit Lembaga Penelitian dan Pengabdian Pada Masyarakat Universitas Muslim Nusantara Al Wasliyah.

Ambarita, Esron. (2017d). Denominal Verbs in Toba Batak Language. The Episteme: Journal of Linguistics and Literature, Volume 3 Number 3, May 2017, ISSN 2442-9392 (Print), ISSN 2460-3236 (Online), Medan: Published by English 
Department, Faculty of Language and Arts Nommensen HKBP University, Medan, Indonesia.

Aronoff, Mark. (1976). Word Formation in Generative Grammar. Cambridge: The MIT Press.

Dardjowidjojo, Soenjono. (1983). Beberapa Masalah dalam Teori Morfologi Jeneratif: Suatu Kasus dalam Pembentukan Kata Kerja in Beberapa Aspek Linguistik Indonesia. Seri ILDEP, Jakarta: Penerbit Djambatan.

Dardjowidjojo, Soenjono. (1988). Morfologi Generatif: Teori dan Permasalahan in PELLBA I Pertemuan Linguistik Lembaga Bahasa Atma Jaya: Pertama, Penyunting Soenjono Dardjowidjojo, Jakarta: Lembaga Bahasa Unika Atmajaya.

Halle, Morris. (1973). Prolegomena to a Theory of Word Formation. Linguistic Inquiry Volume IV Number I, 3-16 Winter, 4(I) I/73 (1-108) ISSN 0024-3892.

Haspelmath, Martin and Sims, Andrea D. (2002). Understanding Morphology. New York: Oxford University Press.

Loe, Efron Erwin Yohanis. (2018). Morfologi Bahasa Rote Dialek Dengka: Kajian Morfologi Generatif. Doctoral Dissertation, Study Program: Linguistik Pascasarjana Universitas Udayana, Denpasar.

Murdianto, 2000. Proses Pembentukan Kata Bahasa Jawa: Sebuah Kajian Transformasi Generatif. Tesis, Program Magister (S2) Linguistik Universitas Udayana, Denpasar.

Nasution, Khairina. (2011). Pembentukan Kata dalam Bahasa Indonesia yang Berasal dari Bahasa Arab: Kajian Morfologi Generatif. Doctoral Dissertation, Study Program: Linguistik Pascasarjana Universitas Sumatera Utara, Medan.

Scalise, Sergio. (1984). Generative Morphology. Dordrecht-Holand/Cinnaminson-USA: Foris Publications.

Sembiring, Milisi. (2016). Theory and Practice in Language Studies, Vol. 6 No. 6 June 2016.

Sembiring, Milisi. (2015). Translating Daliken si Telu Texts in Karonese Society into English. International Journal of Language Studies. Vol. 9 Number 3, Juli 2015 (pp. 131-146).

Simpen, I Wayan. (2008). Afiksasi Bahasa Bali: Sebuah Kajian Morfologi Generatif. Linguistika: Vol. 15 No. 29, September 2008.

Sukri, H. Muhammad. (2008). Sistem Morfologi Bahasa Sasak Dialek Kuto-Kute: Kajian Transformasi Generatif. Doctoral Dissertation, Study Program: Linguistik Pascasarjana Universitas Udayana, Denpasar.

Zainuddin. (2012). Sistem Morfologi Bahasa Gayo: Kajian Transformasi Generatif. Doctoral Dissertation, Study Program: Linguistik Pascasarjana Universitas Sumatera Utara, Medan. 